\title{
GAPS IN THE LEGISLATION HALAL IN MALAYSIA: A STUDY OF LITERATURE
}

\author{
Azis Jakfar Soraji ${ }^{1}$ Mohd Daud Awang ${ }^{2 *}$ Ahmad Nasir Mohd Yusoff ${ }^{3 *}$ \\ 1Unversiti Kuala Lumpur,Malaysia (student PhD UPM), azis@unikl.edu.my \\ ${ }^{2}$ Dr.,Universiti Putra Malaysia, Malaysia, amdaud@upm.edu.com \\ ${ }^{3}$ Dr.,Universiti Putra Malaysia, Malaysia, ahmadnasir@upm.edu.my \\ ${ }^{*}$ Corresponding authors
}

\begin{abstract}
Islam is a well known religion that is perfect, complete, and the rules covering all aspects of human life to achieve happiness in this world until hereafter. Islam encouraging on its followers to choose the good path in every aspect of life, including social, economic and political. In Malaysia, several regulations have been put in place relating to certification or halal labeling. The main complaints related to the halal certification in Malaysia regarding the existence of a number of halal certification bodies, which have created confusion among users of Islam and law enforcement issues halal. The purpose of this article is to analyze the reasons for these discrepancies and offer some practical solutions from a legal standpoint. The research methodology that had been used in this paper is library research methods. The descriptive analysis and content of reading material and relevant law provisions used in the discussion. The findings from the analysis of the data collected shows that the provisions of existing laws, especially the Trade Descriptions Act 2011, are not equipped to deal with the issues and challenges for halal certification while, especially regarding the control over the bodies of halal certification which offers halal certification people and issues of enforcement and prosecution. In addition, the absence of a lawful act is also a challenge to those responsible for working towards the formulation and eventually to be implemented, especially in Malaysia.
\end{abstract}

Keywords: Gap Law Halal, Halal Act, the principles of halal.

\section{INTRODUCTION}

Islam is a holistic religion that covers in every aspect of life that required by such human faith, worship, Islamic, munakahah (weddings), crime and morality. In other words, Islam had been implementing the law, legislation and regulations against all actions and matters affecting human life. The Islamic law is intended to celebrate the life of mankind. Therefore in order to realize the purpose God has made it clear to mankind in the laws that had been translated in Islam. 
There are much increasingly demand in halal industry not only in Malaysia but in several countries around the world. This follows the world's population is expected to increase to more than 57 countries in the world which has a majority Muslim population. It is estimated that up to 2010 the Muslim population increased to three billion people by 2025 while the number has increased to 30 per cent of the total world population. This fact shows clearly we must have a standard and proper laws that comprehensively and effectively to ensure every product meets halal requirements of Islamic law which is marketed in accordance with the purposes of the Quran surah al-Baqarah verse 172-173. (Zulkifli 2007). The average community is now increasingly understand the concept of halal brought by Islam that is universal and comprehensive and not a mere religious ritual (Baharuddin, 2014).

Halal Malaysian law keeping pace with the rapid growth of the halal industry in the country. The relevant provisions of halal in Malaysia has been governed under the Trade Descriptions Act 2011 (Liziana, 2014). In addition there are some other legislation referred halal-related such as the Trade Descriptions (Certification and Marking of Halal) 2011, the Trade Descriptions (Definition of Halal) 2011, the Rules of the Trade Descriptions (Fi Certification and Marking of Halal) 2011, the Food Act 1983, Regulation Food 1985, the Animal Act 1953 (Revised 2006), the Animals, 1962, the Order of Animals (Importation) 1962, the Abattoirs (Privatization) Act 1993, the National Livestock Development Authority (Dissolution) Act 1983, the Local Government Act 1976, Act Small Parties Local authorities, the Consumer Protection Act 1999, the Customs Act 1967, the State Syariah Criminal Offences Enactment and several other acts.

Since 1974, JAKIM has been involved in the verification of the status of halal food products and consumables Islam in Malaysia. Department of Islamic Development Malaysia (JAKIM) and State Islamic Religious Council (MAIN) represent the responsible party in the affairs of halal in Malaysia (Liziana, 2014). Besides, the Ministry of Domestic Trade, Cooperatives and Consumerism Ministry, the Department of Standards Malaysia, the Department of Veterinary Services, Ministry of Health, the Customs Department of the Royal Malaysian Customs and Local Authorities (Zulkifli, 2007) received the cooperation from government agencies in enforcing the law permitted. In addition, there is close cooperation with the Halal Industry Development Corporation (HDC) or also known as the Halal Industry Development Corporation in developing the halal industry in Malaysia in line with efforts to make Malaysia a leading international halal hub.

\section{PURPOSE OF STUDY}

This article aims to identify gaps in legal terms halal in Malaysia and identify some of the issues and legal challenges Halal Malaysia further proposed improvements of existing legislation on food and halal products in Malaysia in the future.

\section{RESEARCH METHODOLOGY}

The initial analysis was done by looking at the legal provisions in various laws related to the halal industry in Malaysia. Collecting materials from books and journals from previous studies had been collected. From these materials the authors conclude there is some gap in the legislation needs to be fixed kosher and made critical improvements to the food industry and halal products in Malaysia are in a position of excellence. The research methodology that had been used in this paper is library research methods.

\section{DISCUSSION}

\subsection{Definition of Halal}

The term "halal" refers to the area of living arrangements of Muslims that guided by halalan tayyib, namely purity, hygiene and healthy living as well as halal (Mohamed Jusoh, 2001; Halim Ahmad, 2001). The "halal" food which is capable of forming personal skills that ultimately contribute to the formation of the nation. As Muslims, we must ensure a source of food and beverages is lawful and meet Islamic dietary guidelines (Surah al-Baqarah 2: 168).

Halal is an Arabic word name. The basic halla, yahillu, Millan which means free, release, break, dissolve and allow (Abdul Aziz, 1997). Terms halal opposed to illegal or out of something illegal. (Wizarah al-Awqaf, 1990). According to Kamus Dewan (2005), halal is well defined as halal law permits an act is done (in Islam), illegal (not forbidden by Islam), permitted, allowed. Term aspect, the halal means permitted, while also something illegal is prohibited.

In addition, halal according to al-Qaradawi (1994), something that is required, that no binding ban and allowed her to do so by legislation. Clearly, halal is something that is a must and allowed Islamic law (alAwqaf Wizarah, 1990). Al-Ghazali (1998) and al-Qaradawi (2002) also clarifies the meaning of halal, which 
covers all major sources of human food either from animals, plants, natural materials, chemicals and microorganisms contained between lawful and unlawful law. Halal and haram debate also involves elements of biotechnology in food products and other personal goods, such as clothing, toiletries and cosmetics. Based on the definition of the language and terminology, it can be concluded that the halal refers to something that is legal in Islamic law for humans eat, use, and so on (Harlida, 2014)

Halal food products alone is not sufficient but must include aspects of "good" (tayyib) that is clean, safe and quality. Since the production of a food product comprising a particular process, starting from the selection, preparation of materials, manufacture, production, storage, transfer, distribution until the product is presented to the user, then the "halal" should cover the whole network starting from its source. This concept is related to legislation in Malaysia, to meet the legal framework existing under several provisions of the law in Malaysia. However, Malaysia has many laws related to Halal, such as deeds, institution or department in charge of the Islamic religion, the ministry's jurisdiction, jurisdiction and enforcement. This has a big challenge in the implementation of the law in Malaysia Halal.

\subsection{Halal Act in Malaysia}

Halal development in Malaysia began with the Muslim community awareness regarding monitoring system Halal food company in Malaysia. In 1968 the Conference of Rulers has decided a proper guideline need to be establish among Malaysian Muslims. As a result of these discussions, the Secretariat of the National Council for Islamic Religious Affairs Malaysia was established. In 1974, the relegious division has been upgraded to the Islamic Affairs Division. Islamic Affairs Division start engaging directly drawing this to provide halal food and consumables. Recognition of halal at this stage, given in the form of a letter and are initially limited to food and consumables products produced by local entrepreneurs. Starting in 1994, Halal recognition is no longer in the form of a letter, but in the form of a certificate to the employer together with Halal logo to be used or displayed on the goods.

Nowday, there are more than 20 certificates that can be referred to the halal certification in Malaysia (Che Rosmawati, 2015; Abdul Rauf, 2014). However, this discussion will only see the number of acts such as the Consumer Protection Act 1999, Trade Descriptions Act 2011, the Trade Descriptions (Certification and Marking of Halal) 2011, the Trade Descriptions (Definition of Halal) 2011, the Food Act 1983 and the Food Regulations 1985 and Food Hygiene Regulations 2009, the Animal Act 1953 (Revised 2006), the Animals (Importation) 1962, the Abattoirs (Privatization) Act 1993, the Local Government Act 1976, Laws of Local Authorities, the Customs Act 1967, Penal Code and some State Syariah Criminal Offences enactment.

\subsubsection{Consumer Protection Act 1999}

The Consumer Protection Act 1999 (APP 1999) is a major act of a savior to most users and usability problems in the country. APP 1999, the Consumer Claims Tribunal was established in order to listen, hear and judge cases of consumerism. The Consumer Protection Act 1999 (APP 1999) began to take effect on 15 November 1999 after more than ten years of discussions initiated. APP 1999 is divided into 14 parts and contains 150 sections covering various aspects of the protection of consumers. Although APP in 1999 is expected to solve the problem of consumerism in the country, specifically it just covers the protection in respect of goods and services offered or provided to the user. In terms of the definition of "goods", it means that goods purchased or used for personal purposes, household or for household purposes. This means, according to APP in 1999 to protect consumers from the use of certain items that are not "products" while the halal aspect also involves a process for the production of the product. Process and the production of these products is often through methods and procedures of chemical and scientific. To meet the demands of a product halal, of course this whole process must be taken into account but it clearly does not belong to what is summarized under APP 1999. Even under section 19 (6) of Part III of the Act expressly excludes food and beauty items. This clearly shows that the legislature intended the concept of consumer protection failed to protect consumers from the more macro aspects, especially in food products.

\subsubsection{Trade Descriptions Act 2011 (APD 2011)}

Although APP in 1999 is seen as failing to protect users from the food product, still exist other legislation that is still able to handle this problem. The law is meant specifically for halal products is the Trade Descriptions Act 2011 (APD 2011) which came into effect in January 2011. The APD 2011 is approved by the Parliament by replacing the Trade Descriptions Act 1972. The main objective of the PPE 2011 is to promote good trade practices by prohibits false trade descriptions and representations, control and false or misleading practices related to the supply of goods and services and to provide for matters connected.

Under Section 28 and 29 APD 2011, three orders have been established, namely the Trade Descriptions (Certification and Marking of Halal) 2011, the Trade Descriptions (Definition of Halal), 2011 and the Rules of 
the Trade Descriptions (Fi Certification and Marking of Halal) 2011 (Ahmad, 2012 ). This is to replace two previous directives, namely the Trade Descriptions Order 1975 and the Trade Descriptions (Marking of Food Fi) 1975. Section 29 APD 2011 also provide a space for the creation of institutional mechanisms to manage and control the affairs related to halal certification (Harlida , 2014) in which the minister may nominate authorities to certify, marking, supplies or offers of goods, including those related with halal certification.

JAKIM authorized prosecution as the ministry rather than just a witness before the amendments made APD 2011 (Liziana, 2014). The prosecution will be conducted in a civil court under the provisions of the law under APD 2011 and other civil law related (Liziana, 2014). The prosecution was made in the civil courts is broader because its jurisdiction includes Muslims and non-Muslims but also the punishment more severe than that of the jurisdiction of the Syariah court (Liziana, 2014). But for offenses related to halal products that are classified as Syariah criminal offenses, the power to prosecute rests with the Chief State Prosecutor (Liziana \& Mariam, 2014). The prosecution process is becoming increasingly easy for JAKIM when Paragraph 4 (3) of the Trade Descriptions (Definition of Halal) Order 2011 provides that the burden of proof rests with the party who is accused (Liziana, 2014) in which the accused will have to prove that they do not make mistakes.

Based on to the provisions listed key, as a whole, the PPE 2011 provides legislation relating to good trade practices, fair and in particular to safeguard the rights of consumers. Trade description here means a user, either directly or indirectly, given by any means in respect of goods in relation to matters such as the type or name; method of manufacture, production, processing or reconditioning; content; testing by any person and results thereof; place or date of manufacture, production, processing or reconditioning and others.

Issues related to halal products, APD 2011 is the starting point for the implementation and certification of halal certification standard in Malaysia. To address the issue of misuse of certificates and certification with more effective and comprehensive, sections 28 and 29 APD 2011 clearly authorizes the Minister to establish specific provisions and relevant. In other words, the APD 2011 provides a common platform related to good trade practices. At the same time, it allows the Minister to make regulations or orders relating to the use of certain goods or services. The result was two special provisions relating to halal certification of the Trade Descriptions (Definition of Halal) Order 2011 and Trade Description (Certification and Marking of Halal) 2011. (Alias, 2013)

\section{The Trade Descriptions (Definition of Halal) 2011}

Paragraph 3 of the Trade Descriptions (Certification and Marking of Halal), 2011 (hereinafter referred to as the Marking of Halal) has named the Department of Islamic Development Malaysia (JAKIM) and State Islamic Religious Council (MAIN) as the agency halal certification credible in Malaysia in recommending a food, goods or services as halal according to the definition of Halal 2011. these provisions have prevented entrepreneurs from misusing halal certificate and logo with the standardization of halal logos can facilitate user Muslims choose halal products on the market (Liziana, 2014).

Command Halal Labelling has introduced two methods in making recommendations regarding halal food and imported goods sold in Malaysia (Harlida, 2014). First, the import of goods that can get the halal certification from by JAKIM or MAIN halal logo and is marked with this body. halal certificate can be obtained from overseas halal certification bodies and producers recognized by by JAKIM such as Australia, New Zealand, Belgium, China, Japan and Indonesia (Harlida, 2014; Liziana, 2014).

A violation of of any provision of these by any party is deemed to have committed an offense under paragraph 8 (a) Command Halal markings. If convicted, the company committed the offense will be fined not more than RM200,000 for the first offense and for a second or subsequent offense is not more than RM 500,000 . The penalty for an individual is a fine not exceeding RM100,000 or to imprisonment for a term not exceeding 3 years or both. For a second or subsequent offense is a fine not exceeding 250,000 or imprisonment not exceeding 5 years or both.

\subsubsection{Food Act 1983}

Food Act 1983 and regulations such as the Food Regulations 1985 and Food Hygiene Regulations 2009 serves as legislation that protects consumers by ensuring that any food supplied can not contain elements that are harmful to health either in terms of food preparation, sale and consumption something foodstuffs (Zulkifli, 2007). This Act empowers the Ministry of Health (MOH) to monitor pelabalen food, hygiene and food safety; ensure that food does not contain substances harmful to health and fit for human consumption. (Norazla, 2015)

Section 13 (1), for example a ban on the supply or sale of harmful food. While section 16 prohibits the preparation, packaging, labeling, sale of any food that is wrong, misleading and there are elements of fraud in terms of its character, value, content, quality, safety, authenticity, weight and others. Although halal is not 
mentioned explicitly in the Act, but the provision also takes into account the aspect of cleanliness, purity, health and quality of foods that meet Halal as part of the concept țayyib (Harlida \& Elias, 2014).

\subsubsection{Food Regulations 1985}

Food Regulations 1985 contain provisions related to sampling procedures, labeling, packaging and so on. Among the areas of concern in Food Regulations this is a matter relating to food labeling, the language used, the grain labeling, form and manner of labeling, size and color of the letters, marking the date, a statement of the strength of the ingredients, packaging in retail premises and what is prohibited. Although halal labeling untouched in this regulation but indirectly it also touched on the description of halal (Harlida, 2014) as set out in the Trade Descriptions (Certification and Marking of Halal) 2011.

\subsubsection{Food Hygiene Regulations 2009}

Regulations of Food Hygiene 2009 (hereinafter referred to as the Food Hygiene Regulations) prescribe matters relating to food hygiene, including food premises used in the preparation, preservation, packaging, storage, shipment, distribution or sale of any food such as factories, restaurants and food truck. This regulation also includes relabelling, reprocessing or reconditioning of food. This rule is also relevant in discussing matters related to the concept of halalan țayyib when hygiene and health concern, including the premises of a food preparation and processing (Harlida, 2014).

\subsubsection{Animals Act 1953 (Revised 2006)}

This Act, together with the Abattoirs (Privatization) Act 1993 and its regulations like Regulation Animals 1962 and Order (importation) Pets 1962 has empowered the Ministry of Health (MoH) and the Department of Veterinary Services (DVS) of the Ministry of Agriculture and Agro-based Industry on farming and animal disease control, especially for the halal certificate application process for meat imports. This is because, being a requirement that a slaughterhouse outside the country have received recognition for imported beef to Malaysia and the Ministry of Health's role is to confirm the safety of the slaughterhouse abroad who have applied Halal certification recognition abroad. Before all meat imported into Malaysia is recognized as Halal, three officers from Malaysia will visit the slaughterhouse; officials of the VSD will examine the situation of livestock, officials from the Ministry of Health $(\mathrm{MOH})$ will examine the safety of animal feed as well as officers from JAKIM slaughter shall ensure that procedures are in accordance with Islamic law.

\subsubsection{Customs Act 1967}

Customs Act 1967 and the Customs (Prohibition of Imports) Order 1988 has empowered the Royal Malaysian Customs on the issue of the importation and the entry of halal products from outside the country who have been tabulated in Table 3, the Customs (Prohibited Imports) Regulations 1988. JAKIM has been allowed to make the recognition of foreign halal certification body to verify the halal status of sources of raw materials and finished or semi-finished products issued by certain countries for the purpose of importation. Importers or manufacturers of products certified as halal by overseas halal certification bodies recognized by JAKIM shall mark the product with the halal logo or the name of the certification body. (Norazla, 2015)

\subsubsection{Local Government Act 1976}

Local Government Act 1976 and the By-Laws of Local Authorities such as the Food Premises Regulation and Licensing and Advertising gives jurisdiction to the local authorities in ensuring the cleanliness of food premises. Each trader must ensure that the premises and the food sold is clean. Indirectly, the local authorities can help to promote the virtues of halal products which should include health aspects (healthy), hygiene and safety (clean \& safe-hygiene), nourishing (nutritious) and quality. (Norazla, 2015)

\subsubsection{Syariah Criminal Enactment}

There is a law a criminal offense under Sharia states that the offense of abuse of the halal. Among the Syariah Criminal Offences (Federal Territories) Act 1997 which provides for the labeling of halal food to Islamic Religious Affairs Department which is the religious police has jurisdiction for the enforcement of this law (Zulkifli, 2007).

Section 42 of the Syariah Criminal Offences (Federal Territories) Act 1997 already provides for such punishment to any indidividu exhibiting any food or drink that is not halal with any sign indicating that the food or drink is halal. If the convicted person to a fine not exceeding RM5,000 or imprisonment not exceeding three years or both.

In addition, section 59 (6) of the Syariah Criminal Offences Enactment (State of Sabah) 1995 has additional provisions; when halal slaughter animals without permission Majlis Agama Islam Negeri Sabah is also an 
offense that is punishable by a fine not exceeding one thousand ringgit or to imprisonment for a term not exceeding six months or both (Zulkifli, 2007).

\subsubsection{Penal Code}

The penal code is also a law that indirectly attributable to the halal products. Section 415 provides for those who are not honest attract people to buy and pay for goods produced is calculated as a fraud and is liable to imprisonment not exceeding five years or a fine or both.

\subsection{Institution: Department of Islamic Development Malaysia (Jakim)}

Generally, JAKIM is the body that has provided guidelines for comprehensive halal products. These guidelines include procedures for inspection, verification and application certificates, approvals, conditions, monitoring and enforcement. For the procedure preliminary checks on plant producers and food premises inspections are performed by at least two officers of Islamic Affairs Officer and Technical Officer (Officer of Food Technology), and inspection of abattoirs also be carried out by at least one officer Islamic Affairs and a technical officer.

The certificate for food products and beverages, consumables, food premises and slaughterhouses produced or manufactured in Malaysia issued by Jakim or the State Islamic Council. For products manufactured outside Malaysia, JAKIM no longer need to issue the halal certificate and logo as the company concerned could use certificates and halal logo issued by the Agency for Muslims in the country as recognized by Jakim halal certificate issued by the Thai state. To obtain the halal certificate of approval, it will only be issued if the application may be approved by the Halal Validation Panel. Any appeals relating to halal certification shall be made in writing to the Director General or the Director of Jakim or the State Islamic Council.

In terms of monitoring and enforcement of the refinery, food premises, slaughterhouses which have gained the Halal Certificate from the authoritative or puts the halal label or logo will be monitored. Monitoring of inspection is bound by law to the Trade Descriptions Act 2011, which allows the enforcement action and prosecution carried out when necessary and relevant. After the completion of the inspection made monitoring notices include Notices shall be issued a warning for minor offenses and major category, Notice of Withdrawal The certificate for category colossal mistake and Notice of Temporary Suspension The certificate if the premises are subject to suspension while Halal certification.

\section{IMPROVEMENT GAPS}

\subsection{The issue of Enforcement}

On the issue of the extent to which the effectiveness of the enforcement authorities by JAKIM from a legal standpoint will be review. The provisions of the existing law only provides for withdrawing JAKIM's halal certification is without jurisdiction to prosecute. Any prosecution will be conducted by the Domestic Trade and Consumer Affairs, and while most of the monitoring and enforcement is carried out by JAKIM. In summary, JAKIM function is to verify the error in the halal issue in addition to being a witness to such cases. Only KPDN and HEP have the power to confiscate, compound and claimed that the owner of the company, whether Eateries, Food Products and Slaughterhouse. Therefore, there is still a lack of enforcement where JAKIM only play a monitoring role, certifying officers to witness the offense and related cases. Should be a body to issue the certification, it also should be given more power to ensure the effective enforcement within the scope of halal products. Issues and problems that arise also is JAKIM does not have any real power of the law which could help launch the lawful enforcement of its own without relying on any other agency. (Zulkifli, 2007).

\subsection{The issue of prosecution}

Referring to the issue of the prosecution, it is also often associated with the issue of enforcement. Related enforcement of halal products is carried out by the prosecution done by JAKIM while KPDN and HEP. If reviewed, and the Domestic Trade and Consumer Affairs not only did the prosecution in the case of halal products but most cases they involve a wide range of other offenses. KPDN and HEP has no special units halal while the prosecution has JAKIM Halal Hub Division of Monitoring and Enforcement Branch itself. Generally if you look at the implementation and enforcement of the prosecution is happening now is that there are some problems and lack of its effectiveness angle. This is because it is run by two different parties.

From another angle, if JAKIM would like to take the prosecution, there are some things that should be noted. The first is the requirement that employees have the qualifications to work in the civil courts. This is because the jurisdiction of the prosecution of halal products is under the jurisdiction of the civil courts. The second is 
the need for legal provisions that authorize JAKIM officials to prosecute. The third is that there are also offenses related to halal products categorized as syariah offenses such as Section 42 of the Syariah Criminal Offences (Federal Territories) Act 1997. In this case, the power to prosecute rests with the Chief Prosecutor states. Therefore, any proposal to grant the prosecution JAKIM officials require consideration from all angles before it can be realized. (Zulkifli, 2007).

\subsection{The drafting of the Halal Malaysia Act}

The debate on the drafting of the Halal Malaysia started since 2010. The Malaysian government has announced to draft a Halal Act for the purpose of coordinating and strengthening the legal provisions concerning the processes, procedures and controls halal certification in the presentation of the budget in 2010. But until today, the Act has not been tabled in Parliament to become a law. (Ahmad, 2012).

The proposed Halal Act, among others, aims to give absolute authority to JAKIM halal certification in monitoring and law enforcement. With the powers conferred upon it, some of the initiatives can be made by JAKIM as obliging companies, individuals, factories, abattoirs to obtain and use the halal logo. So far the application halal certificate and logo is done voluntarily. In addition, placing a full-time religious officials who are paid to supervise the process of halal food production more effectively to misuse halal certificate and logo does not apply. Next oblige manufacturers to put labels on every product produced from materials that are not halal for Muslim consumers avoid fooled by products that are not halal. In fact, operators are required to attend courses slaughter slaughter according to Islamic laws. (Zalina, 2004)

In addition, the Act aims to coordinate a number of matters related to the halal is under the jurisdiction of various ministries and government agencies such as the Ministry of Health, Ministry of Agriculture, Customs, and local authorities. (Ahmad Hidayat \& Zulzaidi, 2012). JAKIM officials expected it will have its own jurisdiction and no longer need to rely on the ministry (Zalina, 2004). Should be the authoritative body in halal certification, JAKIM not only have the power of enforcement but include control, inspection, monitoring, legal education and legal awareness programs for operators and users (Liziana, 2014).

Halal seen the enactment of this has its own limitations. Among the issues expected to arise is when the matter involves constitutional issues related to the Islamic religion will be placed under the jurisdiction of the city. An understanding and compromise among states is needed if all parties want to see the proposed Halal Act is a law that can be enforced because the proposed Halal Act is seen to be taking some inherent power in the relevant agencies to put completely under JAKIM (Ahmad, 2012)

HDC supports the proposal to establish a Halal Act that, but this act must focus on the halal industry as a whole. The Halal issue of should go beyond the law existing because basically there are four key points to be considered halal food products, namely health aspects (healthy), hygiene and safety (clean \& safehygiene), nourishing (nutritious) and (quality). "It must focus on Halal industry as a whole". "Deservedly halal laws need to promote the virtues of halal products." (Mohd Romzi, Interviews, 27 April 2015) (Norazlah, 2015)

\section{SUMMARY}

Based on the discussion above, Malaysia already have a clear guidelines on halal products as well as comprehensive and extensive scope of existing law. However, it was found that there are issues that need to be addressed and focus either in terms of enforcement and prosecution. From the aspect of enforcement, it appears there are still shortcomings where JAKIM only play a monitoring role, confirming the error and its officers as witnesses related cases including the issue of the standardization of halal logo. JAKIM also has wider powers than the law which could help launch the lawful enforcement work without relying on any other agency. From the aspect of prosecution, there are two main issues, namely the effectiveness of prosecution by KPDN and HEP, and constraints that should be considered if JAKIM want to take over the function of prosecution. The most important in the formulation of the act is strictly lawful because it will give space to the implementation of halal in Malaysia much better.

\section{REFERENCE LIST}

Abdul Aziz Dahlan, et al., (1997). Ensiklopedia Hukum Islam. Jilid 2. Jakarta: PT Ichtiar Baru Van Hoeve.

Al-Ghazali, (1998). Halal dan Haram dalam Islam. KL: Jasmine Ent.

Al-Qardhawi, Yusuf, (1994). al-Halal wa al-Haram. Beirut: Maktabah al-Islami. 
Al-Qardhawi, Yusuf, (2002). al-Halal wa al-Haram fi Islam. Kaherah: Maktabah Wahbah.

Alias Azhar et.al, (2013) Produk Makanan Halal: Perspektif Hukum dan Undang-undang. UPM Serdang, Institut Penyedikan Produk Halal Universiti Putra Malaysia.

Abdul Raufu Ambali \& Ahmad Naqiyuddin Bakar. (2014). People's Awareness on Halal Products: Potential Issues for Policy-Makers. Procedia-Social and Behavioral Sciences. 121:3-25.

Ahmad Hidayat Buang \& Zulzaidi Mahmud. (2012). Isudan Cabaran Badan Pensijilan Halal di Malaysia. Shariah Journal. 20(3):271-288.

Baharudin Othman. (2014). Why do food industry need Halal Assurance Management System? A Malaysian approach. Proceeding 5th Annual Conference, International Graduate Conference on Engineering, Science and Humanities 2014.

Che Rosmawati Che Mohd Zaina, Suhaimi Ab Rahman, Zahira Mohd Ishak\& Shamrahayu. (2015). Jurisdiction and Prosecution of Halal Matters in Malaysia: Challenges and Prospect. Procedia- Social and Behavavioral Science.172:294-300.

Harlida Abdul Wahab \& Alias Azhar. (2014). Halalan Tayyiban dalam Kerangka Perundangan Malaysia. KANUN. 1:103-120

Harlida Abdul Wahab dan Alias Azhar(2014) Halalan Tayyiban dalam Kerangka Perundangan Malaysia Jurnal Kanun 26 (1) Jun 2014.

Kamus Dewan ( 2005). Edisi Ke-3. Kuala Lumpur: Dewan Bahasa dan Pustaka.

Liziana Kamarul Zaman \& Mariam Setapa. (2014). Undang-undang Produk Halal di Malaysia: Akta Perihal Dagangan 2011.

Mohd Al'Ikhsan Ghazali \& Sit iSalwa Md. Sawaria. (2014). Amalan Standard Halal Di Negara-Negara Asia Tenggara. International Journal of Islamic and Civilizational Studies, 1: 35-44.

Halim Ahmad, (2001) Penyembelihan dan pemburuan: Antara Tuntutan Syara' dan Sains. Jurnal Penyelidikan Islam Bil. 14, hlm. 89-98.

Mohamed Jusoh, (2001). Halal Haram in Food Ingredients. Jurnal Penyelidikan Islam Bil. 14, hlm. 99-112.

Norazla Abdul Wahab, Farah Mohd. Shahwahid, Nor'Adha Ab. Hamid, Surianom Miskam, Syaripah Nazirah Syed Ager, Marliana Abdullah, Norziah Othman \& Wawarah Saidpudin(2015) UNDANG-UNDANG HALAL MALAYSIA: ISU DAN CABARAN World Academic and Research Congress 2015 (World-AR 2015) Ar-Rahim Hall, YARSI University, Jakarta, Indonesia, 9th - 10th December 2015

Wizarah al-Awqaf wa Shu'un al-Islamiyyah, (1990). Jld.18. Al-Mausu'ah al-Fiqhiyyah. Kuwait: Thaba'ah Zat al-Salasil.

Zalina Zakaria \& Siti Zubaidah .(2014). The Trade Description Act 2011: Regulating "Halal" in Malaysia. Proceeding paper on International Conference on Law Management and Humanatarian. June 21-22, 2014. Bangkok (Thailand).

Zalina Zakaria \& Siti Zubaidah Ismail. (2015). Perkembangan Pengaturan Halal Menerusi Akta Perihal Dagangan 2011 di Malaysia. Jurnal Syariah, Jil. 23, Bil. 2 (2015) 189-216

Zulkifli Hassan, (2007). Undang-undang Produk Halal di Malaysia: Isu Penguatkuasaan dan Pendakwaan. Konvensyen Kebangsaan Undang-undang: Isu Penguatkuasaan dan Pendakwaan. 11-12 Ogos 2007.1-21 